\title{
Development and Optimization of Mini Tractor Mounted Clod Crusher cum Planker
}

\author{
C.J. Ginoya ${ }^{1 *}$, R. Yadav², S.R. Zilpilwar', V.R. Vagadia ${ }^{2}$ and V. Agrawat $^{1}$ \\ ${ }^{1}$ Department of Farm Machinery and Power Engineering, ${ }^{2}$ Department of Farm Engineering, \\ Junagadh Agriculture University, Junagadh, 362001, India \\ *Corresponding author
}

\section{A B S T R A C T}

In tillage tools used in India faces problem like, poor soil-tire interface, clod formation,

\begin{tabular}{|l|}
\hline Ke y w or d s \\
Tillage, Clod \\
crusher, \\
Performance, \\
Spiked roller, etc. \\
\hline Article Info \\
\hline Accepted: \\
12 December 2018 \\
Available Online: \\
10 January 2019 \\
\hline \hline
\end{tabular}
compaction due to heavy traffic and timeliness in operation. Overcome to this practical problem, it was planned to develop a clod crusher cum planker for better seed bed preparation. To achieve this objective a prototype implement consisting of three different types of clod crusher rollers' like square spike, round spike and spiral arrangement of spike were developed. The developed implement was tested in the field to evaluate its performance. Their results were analyzed in terms of breaking of clods and machine parameters. The effects of treatments on soil physical properties like soil bulk density, clod MWD were evaluated. Machine performance parameters like fuel consumption, field efficiency and cost of operation were also studied. The optimum values of clod MWD, clod crushing field efficiency and fuel consumption were found $13.64 \mathrm{~mm}, 78.37 \%$ and $7.02 \mathrm{l} / \mathrm{ha}$ respectively. The operating cost were found 882,1050 and $988 \square /$ ha in case of square spike, round spike and spiral arrangement respectively. Better performance in terms of breaking of clods was obtained using clod crusher of square spike. Using clod crusher a farmer can save money in comparison to traditional methods of preparation of seedbed.

\section{Introduction}

Soil clod refers to a natural lump of soil that exists as an isolated entity in the field. Clod formation is a serious problem to prepare the seed bed. Tillage of a compacted soil results in greater cloddiness than of an uncompact soil (Johnson et al., 1979; Sharma, 2001 and Anon., 2017). Loosening of soil is done to achieve a desired granular soil structure for a seedbed and to allow rapid infiltration and good retention of moisture, to provide adequate air exchange capacity within the soil and to minimize resistance to root penetration and shoot growth. Clod breaking operation is required to produce a granular soil structure in the final seedbed.

Clod formation after ploughing or disking is a major problem in arid and semi-arid zones of India. Clods create obstruction to penetration of furrow openers of seed drill and do not allow intimate contact between seeds and soil. Pulverization of clods is necessary to avoid the above problems (Agrawal and Singh, 1988). Looking to the present practice of seed 
bed preparation among the farmers and implements used to perform different operations, there is need to study the best alternative, either operation wise or equipment wise, by which we can reduce the time, cost of operation, and improves the efficiency of the system.

Soil is the major problem while making seed bed preparation and make soil easy to field operation and therefore this work is undertaken with following objectives.

To develop a mini tractor mounted clod crusher.

To evaluate the performance of the developed machine.

\section{Tillage and seedbed preparation}

Carman (1997) observed that different methods produced different yields, which appeared to relate to the soil conditions produced by tillage. There was a significant $(\mathrm{P}<0.01)$ effect of the four different tillage systems on moisture content, bulk density, penetration resistance, aggregate mean weight diameter and surface roughness.

Sahu and Rahman (2006) stated that it was found that no mathematical equation is available to predict the draft requirement of combination tillage implements. And also found that the draft of all the tillage implements increased with increase in soil compaction, depth and speed of operation.

Patil and Sheelavantar (2009) studied that land development, tillage and seedbed preparation together account for a major share of power utilization in the crop cycle. The implements used for seedbed preparation needs to be evaluated for maximum field capacity with reduced cost of operation. The implements for tillage operation usually pass the farm four times or more which causes soil compaction, increases cost of labour and energy.

\section{Clod cusher}

Maheshwari et al., (2005) evaluated tractordrawn cultivator-spiked clod crusher with planker. The cultivator-spiked clod crusher saved time 18.5, 23.47 and 15.60percent compared to cultivator planker in soybean field, manually harvested paddy field and combine harvested paddy fields respectively. The total tractor hours saved with cultivatorclod crusher as compared to cultivator planker combination was about $1.43,4.25$ and 4.80 $\mathrm{h} / \mathrm{ha}$, which amounted to a saving of about $\square 179,531$ and 600 per hectare at assumed tractor hiring cost of $\square 125 / \mathrm{h}$ for complete seedbed preparation in soybean field (loam type light soil), manually harvested paddy field and combine harvested paddy fields (silty-clay-loam type heavy soil), respectively.

An animal-drawn wheeled tool-carrier with attachment of tools for tillage, seeding and intercultural was developed at IGKV, Raipur (C.G.). The unit consisted of main-frame, toolbar and wheels (pneumatic/iron wheels) with provisions for attachment of tools and lifting of tools on turns. This tool-carrier showed advantage in terms of higher command area (2.0-2.5 times) over conventional implements. The unit with attachments may cost $\square$ 20,000. Its performance as work rate (ha/hr) for sowing, weeding and seed bed preparation was 0.10 , $0.15,0.10$ compared to $0.03,0.07,0.10$ by MB plough, seed drill, cultivar blade hoe respectively. The tool-carrier permitted higher command area per season (4-5 ha) (Anon., 2008).

Pacharne et al., (2009) developed a tractor drawn $\mathrm{V}$ blade harrow which consisted of a mild steel frame and a V shape blade fitted to the frame. The blade was strong and made up 
of high carbon steel. Due to its V shape its penetration in soil was easy which required 35 or more hp tractor. Study was conducted over 20 ha area with following results $0.46 \mathrm{ha} / \mathrm{hr}$ effective field capacity, 95 per cent field efficiency and $416.00 \square$ /ha cost of operation. It was reported 40 percent saving in labour cost, 40 percent field coverage, 3.78 per cent field efficiency, 95 per cent weeding efficiency. The $\mathrm{V}$ blade harrow was found very useful for removing weeds and grasses, clod crushing, uprooting and breaking the stubbles.

\section{Clod mean weight diameter}

Yassen et al., (1992) reported that with low soil moisture content the cohesion force between particles of soil is very strong and a lot of energy is needed during tillage. The ploughing depth is a very important and effective parameter. Increasing the ploughing depth raise the clod mean weight diameter (MWD).

Carman (1997) conducted an experiment on clay soil to understand effect of tillage system and found that penetration resistance was observed to decrease from $830 \mathrm{kPa}$ to $333 \mathrm{kPa}$ depending on tillage depth. Rotary tillage produced a smaller aggregate mean weight diameter $(12.18 \mathrm{~mm})$ than other tool and before tillage $(16.94 \mathrm{~mm})$. Bulk density reduced from $1.27 \mathrm{mg} / \mathrm{m}^{3}$ to $0.985 \mathrm{mg} / \mathrm{m}^{3}$.

\section{Materials and Methods}

A clod crusher was developed to ensure timeliness in seed bed preparation. The clod crusher to cultivator consists of a frame with cultivator tines, spike tooth, framework to mount roller and three-point linkage unit. Schematic diagram of clod crusher cum planker is shown in Figure 1 and 2.

The working principle behind the clod crusher attachment to cultivator which is having clod crusher as active unit behind implement and in front cultivator tines are attached as passive unit. Cultivator tines open the furrow and spike tooth with roller cut and pulverize the soil at optimum condition for the tillage. Clod crusher breaks the clod and converted into small size of the soil particles. The conceptual model of clod crusher with square spike, round spike and square spike but spirally arranged (Fig. 3-5).

\section{Clod crusher}

A clod crusher behind the cultivator was provided to break the clods and to develop the seed bed having fine land levelled tilth and design specification is given in table 1 .

\section{Window}

According to the Figure 6, a window was placed on the roller. This window was made from M.S. plate. The window was used to fill up the sand in the rollers and to increase its weight.

\section{Experimental procedure}

All the parameters of the tractor-implement performance were measured and recorded in line with the recommendations of RNAM (Regional National for Agricultural Machinery) test codes and procedures for farm machinery technical series. Yuvraj tractor (15 hp) was used to test the performance of the clod crusher (Fig. 7 and 8). All the three rollers were tested for preparation of field for seed bed.

\section{Design of the experiment}

The planning of field experiment was done by using analysis of variance (ANOVA) for the Factorial Randomized Block (FRBD) Design (Panse and Sukhatme, 1967). The ANOVA procedure was used to evaluate the 
significance of each parameter and the interactions between parameters. Under which 9 treatment combinations and 4-replication was carried out and 36 number of observation were planned for field evaluation (Table 2).

\section{Soil parameters}

\section{Moisture content of the soil}

Moisture content of the soil was determined by standard oven dry method by keeping sample at the temperature of $105^{\circ} \mathrm{C}$ for 24 hours [IS: 2720-2 (1973)].

Moisture content $\%=\frac{w_{w}-w_{d}}{w_{d}} \times 10$

Where,

$\mathrm{W}_{\mathrm{w}}=$ Weight of the wet soil, $\mathrm{g}$

$\mathrm{W}_{\mathrm{d}}=$ Weight of the dry soil, $\mathrm{g}$

\section{Bulk density of the soil}

Metallic core roller was used to take sample from the field. Samples were taken in $5.4 \mathrm{~cm}$ diameter and $8.8 \mathrm{~cm}$ long core sampler. The dry weight of the samples was calculated from the moisture content (w.b.). The ratio of the dry weight of the soil to the volume gives the bulk density (Punmia and Jain, 2005).

$\underset{W-(\mathrm{W} \times \mathrm{MC} / 100)}{\text { Bulk density }} \quad$ of
$=\frac{}{V}$ (2)

Where,

$\mathrm{W}=$ Weight of moist soil collected, $\mathrm{g}$

$\mathrm{V}=$ Volume of metallic core, $\mathrm{cm}^{3}$

$\mathrm{Mc}=$ Moisture content of the soil, $\%$

\section{Clod mean weight diameter}

To determine the clod mean weight diameter, soil samples were taken randomly from the tilled plots $(15 \times 15 \mathrm{~cm})$, after with and without clod crusher operation. The moist soil samples were allowed to air dry at room temperature for several days. After the primary and secondary tillage, the air-dried soil samples were sieved using a set of sieves (mesh opening 11.2, 8.0, 5.6, 4.0, 2.8, $2.0 \mathrm{~mm}$ and pan) with a shaking time of 30seconds (Eghball et al., 1993).

Measure the mean weight diameter (MWD) of soil aggregate which would be the index for soil pulverization. The clod mean weight diameter was calculated by using the formula given below (Boydas and Turgut, 2007 and IS: 7640-1975).

$M W D=\sum_{i=0}^{n} \frac{w_{i}}{W} D_{i}$

Where,

$\mathrm{W}_{\mathrm{i}}=$ Weight of soil on each special sieve, $\mathrm{kg}$

$\mathrm{W}=$ Total weight of experimented soil, $\mathrm{kg}$

$\mathrm{D}_{\mathrm{i}}=$ Net diameter of each sieve, $\mathrm{mm}$

\section{Machine performance parameters}

\section{Depth and width of cut}

The depth of cut was determined by measuring the distance between horizontal soil surfaces to the bottom of dug out furrow with the help of steel scale. Depth measurements were taken in different places of the field and the average depth was used as the depth of cut. The width of cut was determined by measuring the horizontal distance cut by blade with the help of measuring tape.

\section{Measurement of wheel slip}

It is the relative movement of the wheel in the direction of the travel for a given distance under the percentage slip was calculated using the following formula (Kepner et al., 2005),

Wheel Slip (\%) $=\frac{\mathrm{M}_{2}-\mathrm{M}_{1}}{\mathrm{M}_{2}} \times 100$ 
Where,

$\mathrm{M}_{1}=$ Distance covered by wheel at no load (m),

$\mathrm{M}_{2}=$ Distance covered by wheel with load (m).

\section{Field capacity}

\section{Theoretical field capacity}

The theoretical field capacity is the rate of field coverage that would be obtained if the implement operates continuously without interruption (Kepner et al., 2005 and Sahay, 2008).

$\mathrm{TFC}=\frac{\mathrm{W} \times \mathrm{S}}{10}$

Where,

TFC $=$ Theoretical field capacity, ha/h

$\mathrm{W}=$ Width of cut, $\mathrm{m}$

$\mathrm{S}=$ Forward speed, $\mathrm{km} / \mathrm{h}$

\section{Effective field capacity}

This is the actual rate of field coverage based on field time. This is calculated by measuring area covered by implement and divide by time taken (Kepner et al., 2005).

$\mathrm{EFC}=\frac{\mathrm{W} \times \mathrm{L}}{\mathrm{T} \times 10000}$

Where,

$\mathrm{EFC}=$ Effective field capacity, ha/h

$\mathrm{W}=$ Width of cut, $\mathrm{m}$

$\mathrm{L}=$ Length of strip, $\mathrm{m}$

$\mathrm{T}=$ Time taken, $\mathrm{h}$

\section{Field efficiency}

Field efficiency is the ratio of effective field capacity to the theoretical field capacity expressed as percentage. The field efficiency of the implement was determined using following formula (Sharma and Mukesh, 2010).
Field efficiency $(\%)=\frac{\text { Effective field capacity }}{\text { Theoretical field capacity }} \times 100$

\section{Forward speed}

Outside the boundary of the test plot, two poles with red flags at $30 \mathrm{~m}$ apart were placed approximately in the middle of test run. The time required to travel the distance of $30 \mathrm{~m}$ was recorded and the speed of operation was calculated.

\section{Fuel consumption}

The fuel consumption of the tractor while using implement was measured as per the standard method. The fuel measuring device was used to measure the amount of fuel consumed during tillage operation. Amount of fuel obtained after the test divided by time gives fuel consumption for each test (Mehta et al., 1995).

\section{Draft of implement}

A digital dynamometer was attached to the front of the tractor on which clod crusher attachment to cultivator is mounted. Another auxiliary tractor was used to pull the implement mounted tractor through the dynamometer in neutral gear with and without implement in the operating position. The difference of both the readings gives the draft of the implement (Mehta et al., 1995).

\section{Economics of clod crushing method}

The economics of the clod crushing method application in terms of operation was observed and compared to each other. The cost economics was evaluated by using straight line method (Hunt, 2001).

\section{Straight line method}

In the straight-line depreciation method, an 
equal reduction of value is used for each year the machine is owned. This method can always be used to estimate costs on a specific period of time, provided the proper salvage value is used for the age of the machine.

\section{Results and Discussion}

Field parameters were measured prior to field testing like soil moisture content and bulk density was found $14.18 \%$ (d.b.) and 1.18 $\mathrm{g} / \mathrm{cm}^{3}$ respectively.The operating parameter such as average width of cut, depth of cut and speed of operation was measure and it was found that $120 \mathrm{~cm}, 15 \mathrm{~cm}$ and $3.17 \mathrm{~km} / \mathrm{h}$ respectively.

\section{Wheel slip during field operation}

Wheel slip was determined by standard procedure. Wheel slip (travel reduction) affects the traction efficiency of any tractive device. The effect of wheel slip during operation of different implements was recorded and graphically presented in Figure 9.

\section{Draft requirement}

Draft was determined by standard procedure. The values of draft of different types of roller in different weight of roller were measured and graphically presented in Figure 10. Clod crusher attachment to cultivator having lower draft in case of square spike type roller with $50 \mathrm{~kg}$ of weight and having higher draft in case of roller with spiral arrangement with $150 \mathrm{~kg}$ of weight.

\section{Clod mean weight diameter}

Clod mean weight diameter of the clod crusher during field operation was observed and calculated. ANOVA for clod mean weight diameter on types/weight of roller are presented in Table 3. ANOVA shows that the types of roller and weight of roller both had significant effect on clod mean weight diameter at 5 per cent level. The interaction between types of roller and weight of roller also shows significant effect.

\section{Effect of types of roller on clod mean weight diameter}

Comparisons of mean values of clod mean weight diameter among all three types of roller obtained from statistical analysis. The result revealed that mean values of clod mean weight diameter for all three types of roller were significant at 5 per cent level. The reason for lowest value of clod MWD may be due to higher speed of rotor and lower depth. For clod crusher attachment to cultivator $\left(\mathrm{T}_{3}\right)$ the clod MWD was $13.64 \mathrm{~mm}$, which was medium and required for preparation of seed bed (Singh and Panesar, 1991, Carman, 1997 and Maheshwari et al., 2005). The mean values of clod mean weight diameter at three types of roller were compared and graphically presented in Figure 11. It shows that clod mean weight diameter of $14.73,15.61$ and $15.03 \mathrm{~mm}$ was observed corresponding to the roller of square spike, round spike and spiral arrangement.

\section{Effect of weight of roller on clod mean weight diameter}

The result revealed that mean values of clod mean weight diameter for all three weights of roller were significant at 5 per cent level. The mean values of clod mean weight diameter at three weights of roller were compared and presented graphically presented in Figure 12. It shows that clod mean weight diameter of $16.16,15.08$ and $14.22 \mathrm{~mm}$ was observed corresponding to the weight of roller of 50 , 100 and $150 \mathrm{~kg}$.

Combined effect of types of roller and weight of roller on clod mean weight diameter 
The mean values of the clod mean weight diameter and their significance are shown in Table 4.

The interaction between types of roller and weight of roller was found significant at 5 per cent level of significance. From the table the higher value of clod mean weight diameter is $16.45 \mathrm{~mm}$ in case of round spike and $50 \mathrm{~kg}$ of weight and lower/optimum value of clod mean weight diameter is $13.64 \mathrm{~mm}$ in case of square spike and $150 \mathrm{~kg}$ of weight.

\section{Fuel consumption}

Fuel consumption of the clod crusher during operation was observed and calculated. ANOVA for fuel consumption on types/weight of roller are presented in Table 5. ANOVA shows that the types of roller and weight of roller both had significant effect on installation time at 5 per cent level. The interaction between spool rotation and forward speed also shows significant effect.
Effect of types of roller on fuel consumption

The results revealed that mean values of fuel consumption for all three types of roller were significant at 5 per cent level. The mean value of fuel consumption of three types of roller were compared and graphically presented in Figure 13. Minimum fuel consumption (6.841/ha) was observed in case of square spike type roller and maximum fuel consumption $(7.031 / \mathrm{ha})$ was in roller with spiral arrangement.

\section{Effect of weight of roller on fuel consumption}

The mean value of fuel consumption of three types of roller were compared and graphically presented in Figure 14. Minimum fuel consumption (6.611/ha) was observed corresponding to the weight of $50 \mathrm{~kg}$ and maximum fuel consumption (7.361/ha) was observed corresponding to the weight of 150 $\mathrm{kg}$.

Table.1 Design specifications of clod crushers

\begin{tabular}{|l|c|c|c|c|}
\hline Sr. No. & Particulars & \multicolumn{3}{|c|}{ Dimensions } \\
\hline & & Square spike & Round spike & $\begin{array}{c}\text { Spike of spiral } \\
\text { arrangement }\end{array}$ \\
\hline $\mathbf{1}$ & Diameter of axle rod, cm & 5.08 & 5.08 & 5.08 \\
\hline $\mathbf{2}$ & Thickness of axle rod, cm & 0.5 & 0.5 & 0.5 \\
\hline $\mathbf{3}$ & Diameter of roller, cm & 21 & 21 & 21 \\
\hline $\mathbf{4}$ & Length of roller, cm & 135 & 135 & 135 \\
\hline $\mathbf{5}$ & Total number of spikes & 104 & 104 & 78 \\
\hline $\mathbf{6}$ & Height of spike, cm & 4 & 4 & 4 \\
\hline $\mathbf{7}$ & Size of spike, cm & $2.5 \times 2.5$ & - & $1.5 \times 1.5$ \\
\hline $\mathbf{8}$ & Dia. of spike, cm & - & 1.5 & - \\
\hline
\end{tabular}


Table.2 Details of experimental variable included for the study

\begin{tabular}{|c|c|c|c|}
\hline $\begin{array}{l}\text { Sr. } \\
\text { No. }\end{array}$ & Variables & Parameters & Levels \\
\hline 1 & Independent Parameters & Types of roller, RT & $\begin{array}{l}\mathrm{RT}_{1}=\text { Square Spike } \\
\mathrm{RT}_{2}=\text { Round spike } \\
\mathrm{RT}_{3}=\text { Spiral arrangement (Square Spike) }\end{array}$ \\
\hline & & $\begin{array}{l}\text { Weight of roller }(\mathrm{kg}) \text {, } \\
\text { RW }\end{array}$ & $\begin{array}{l}\mathrm{RW}_{1}=50 \\
\mathrm{RW}_{2}=100 \\
\mathrm{RW}_{3}=150\end{array}$ \\
\hline 2 & Dependent Parameters & \multicolumn{2}{|c|}{$\begin{array}{l}\text { (1) Clod mean weight diameter, mm } \\
\text { (2) Field Efficiency, \% } \\
\text { (3) Fuel consumption, 1/ha }\end{array}$} \\
\hline
\end{tabular}

Table.3 ANOVA for clod mean weight diameter

\begin{tabular}{|l|c|c|c|c|c|c|c|}
\hline \multicolumn{1}{|c|}{ SOV } & DF & SS & MSS & CAL F & TAB F 5\% & SEM & CD \\
\hline RT & 2 & 4.769 & 2.384 & $31.98^{*}$ & 3.40 & 0.079 & 0.230 \\
\hline RW, kg & 2 & 22.884 & 11.421 & $153.43^{*}$ & 3.40 & 0.079 & 0.230 \\
\hline RT $\times$ RW, kg & 4 & 0.571 & 0.142 & 1.915 & 2.78 & 0.137 & NS \\
\hline Error & 24 & 1.789 & 0.074 & CV $\%=1.80$ \\
\hline Total & 35 & 30.151 & $*=5 \%$ significant, NS = non-significant & \\
\hline
\end{tabular}

Table.4 Effect of interaction of types of roller and weight of roller on clod mean weight diameter

\begin{tabular}{|c|c|c|c|}
\hline \multirow{2}{*}{ Types of roller } & \multicolumn{3}{|c|}{ Clod MWD $(\mathbf{m m})$} \\
\cline { 2 - 4 } & \multicolumn{3}{|c|}{ Weight of roller $(\mathbf{k g})$} \\
\cline { 2 - 4 } & $\mathbf{5 0}$ & $\mathbf{1 0 0}$ & $\mathbf{1 5 0}$ \\
\hline Square spike & 15.98 & 14.57 & 13.64 \\
\hline Round spike & 16.45 & 15.52 & 14.86 \\
\hline Spiral arrangement & 16.06 & 14.93 & 14.17 \\
\hline
\end{tabular}

Table.5 ANOVA for fuel consumption

\begin{tabular}{|l|c|c|c|c|c|c|c|}
\hline \multicolumn{1}{|c|}{ SOV } & DF & SS & MSS & CAL F & TAB F 5\% & SEM & CD \\
\hline RT & 2 & 29.25 & 14.62 & $4.007^{*}$ & 3.40 & 0.551 & 1.609 \\
\hline RW, kg & 2 & 259.34 & 129.67 & $35.54^{*}$ & 3.40 & 0.551 & 1.609 \\
\hline RT $\times$ RW, kg & 4 & 11.07 & 2.77 & 0.76 & 2.78 & 0.955 & NS \\
\hline Error & 24 & 87.56 & 3.65 & CV \% $=2.29$ & \\
\hline Total & 35 & 393.17 & $* 5 \%$ significant, NS = non-significant \\
\hline
\end{tabular}


Table.6 Effect of interaction of types of roller and weight of roller on fuel consumption

\begin{tabular}{|c|c|c|c|}
\hline \multirow{2}{*}{ Types of roller } & \multicolumn{3}{|c|}{ Fuel consumption (1/ha) } \\
\cline { 2 - 4 } & \multicolumn{3}{|c|}{ Weight of roller (kg) } \\
\cline { 2 - 4 } & $\mathbf{5 0}$ & $\mathbf{1 0 0}$ & $\mathbf{1 5 0}$ \\
\hline Square spike & 6.61 & 6.89 & 7.02 \\
\hline Round spike & 6.64 & 6.96 & 6.73 \\
\hline Spiral arrangement & 6.71 & 7.00 & 7.36 \\
\hline
\end{tabular}

Table.7 ANOVA for field efficiency

\begin{tabular}{|l|c|c|c|c|c|c|c|}
\hline \multicolumn{1}{|c|}{ SOV } & DF & SS & MSS & CAL F & $\begin{array}{c}\text { TAB F } \\
\mathbf{5 \%}\end{array}$ & SEM & CD \\
\hline RT & 2 & 86.14 & 43.68 & $25.83 *$ & 3.009 & 0.373 & 1.08 \\
\hline RW, kg & 2 & 263.32 & 131.66 & $78.98 *$ & 3.40 & 0.373 & 1.08 \\
\hline RT $\times \mathbf{R W}, \mathbf{k g}$ & 4 & 4.59 & 1.15 & 0.69 & 2.78 & 0.646 & NS \\
\hline Error & 24 & 40.005 & 1.67 & CV \% $=1.78$ & & \\
\hline Total & 35 & 399.78 & $*=5 \%$ significant, NS = non-significant \\
\hline
\end{tabular}

Table.8 Effect of interaction of types of roller and weight of roller on field efficiency

\begin{tabular}{|c|c|c|c|}
\hline \multirow{2}{*}{ Types of roller } & \multicolumn{3}{|c|}{ Field efficiency (\%) } \\
\cline { 2 - 4 } & \multicolumn{3}{|c|}{ Weight of roller (kg) } \\
\cline { 2 - 4 } & $\mathbf{5 0}$ & $\mathbf{1 0 0}$ & $\mathbf{1 5 0}$ \\
\hline Square spike & 71.74 & 73.80 & 78.37 \\
\hline Round spike & 67.34 & 71.11 & 74.13 \\
\hline Spiral arrangement & 69.16 & 72.68 & 75.61 \\
\hline
\end{tabular}




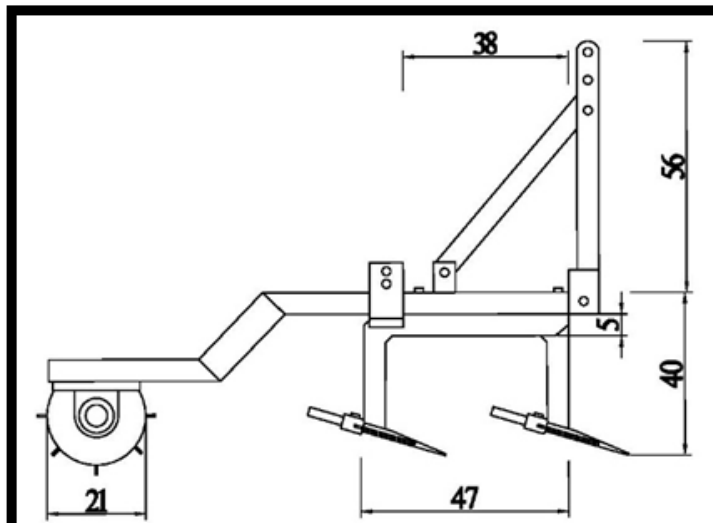

All dimensions are in $\mathrm{cm}$

Fig.1: Schematic diagram showing side view of clod crusher attachment

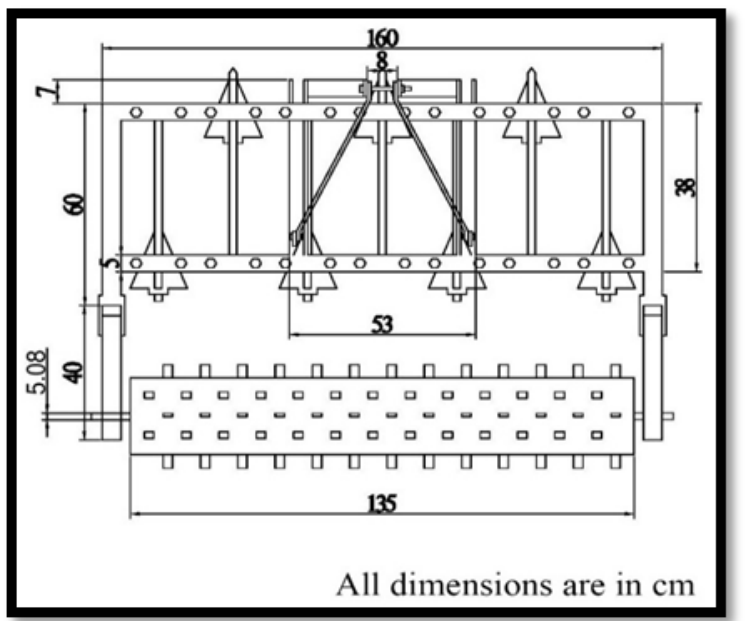

Fig.2: Schematic diagram showing top view of clod crusher attachment

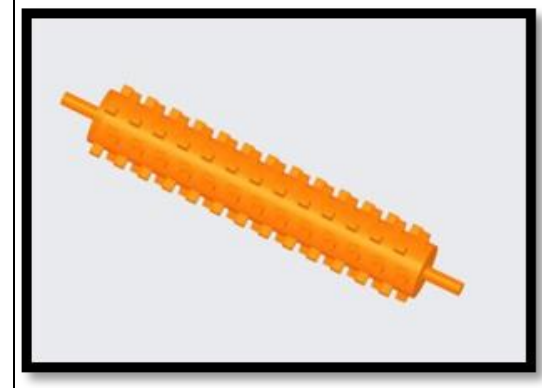

Fig. 3:Conceptual model of clod crushing device with square spike
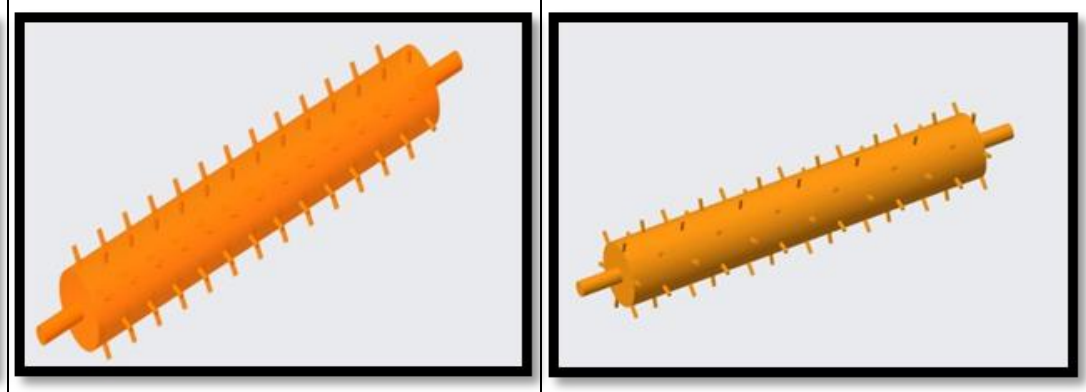

Fig.4: Conceptual model of clod crushing device with round spike
Fig.5: Conceptual model of clod crushing device with square spike(spiral arrangement)

Fig.6 Window for filling up sand

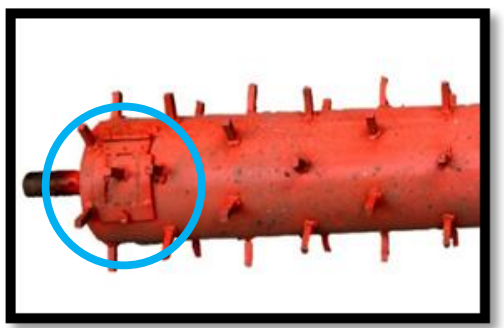




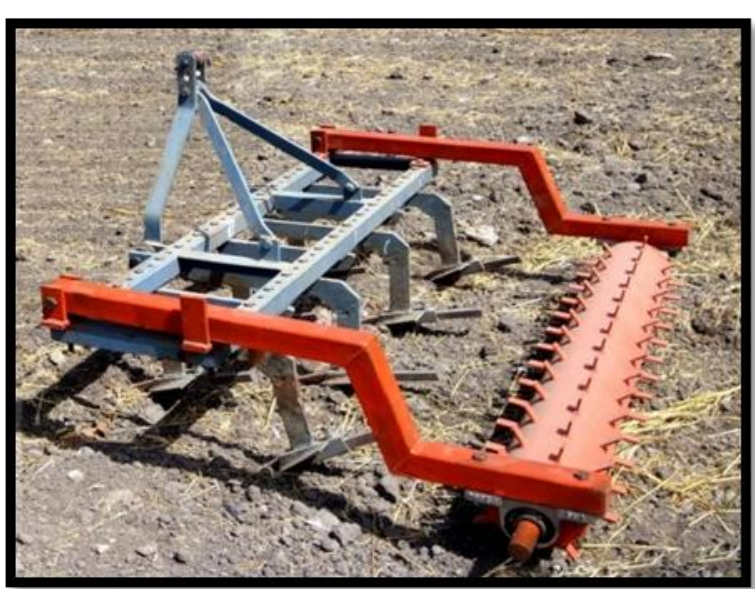

Fig.7:Clod crushercum planker

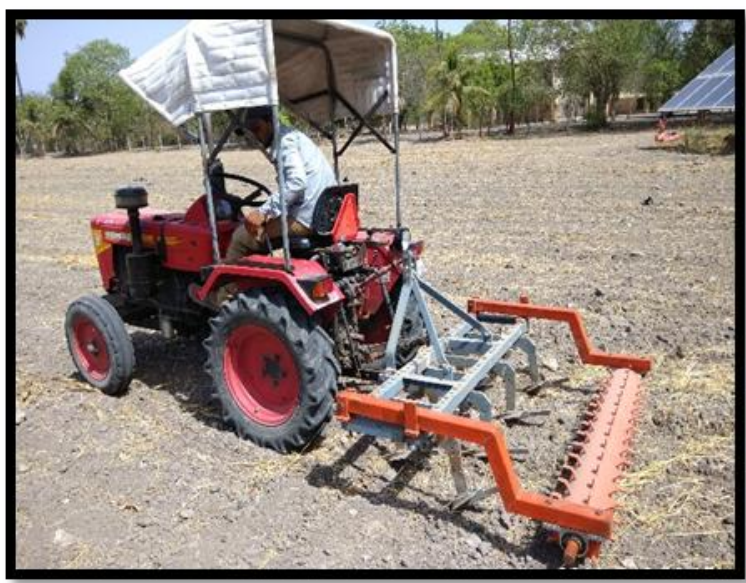

Fig. 8: Clod crusher cum planker with tractor
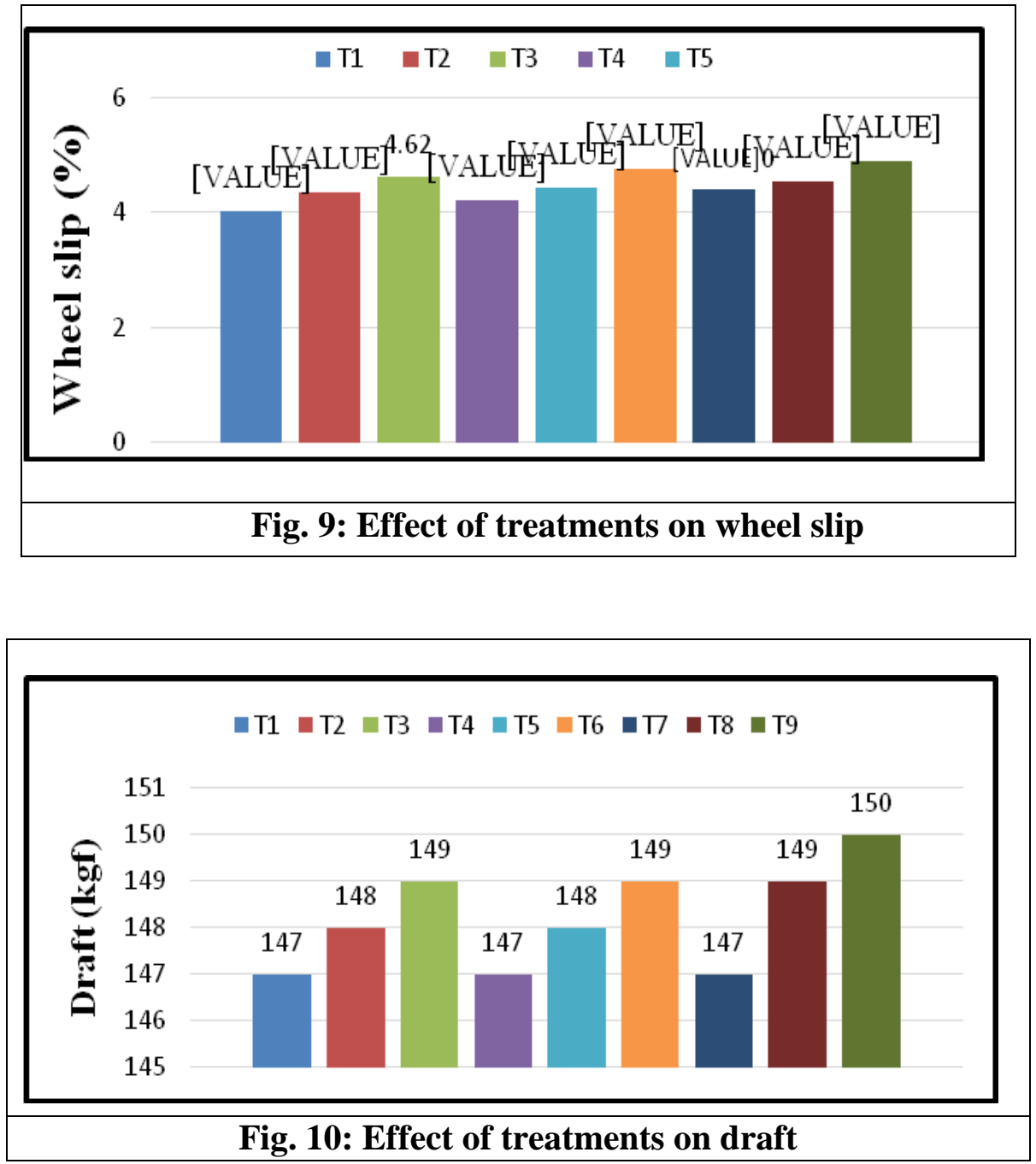

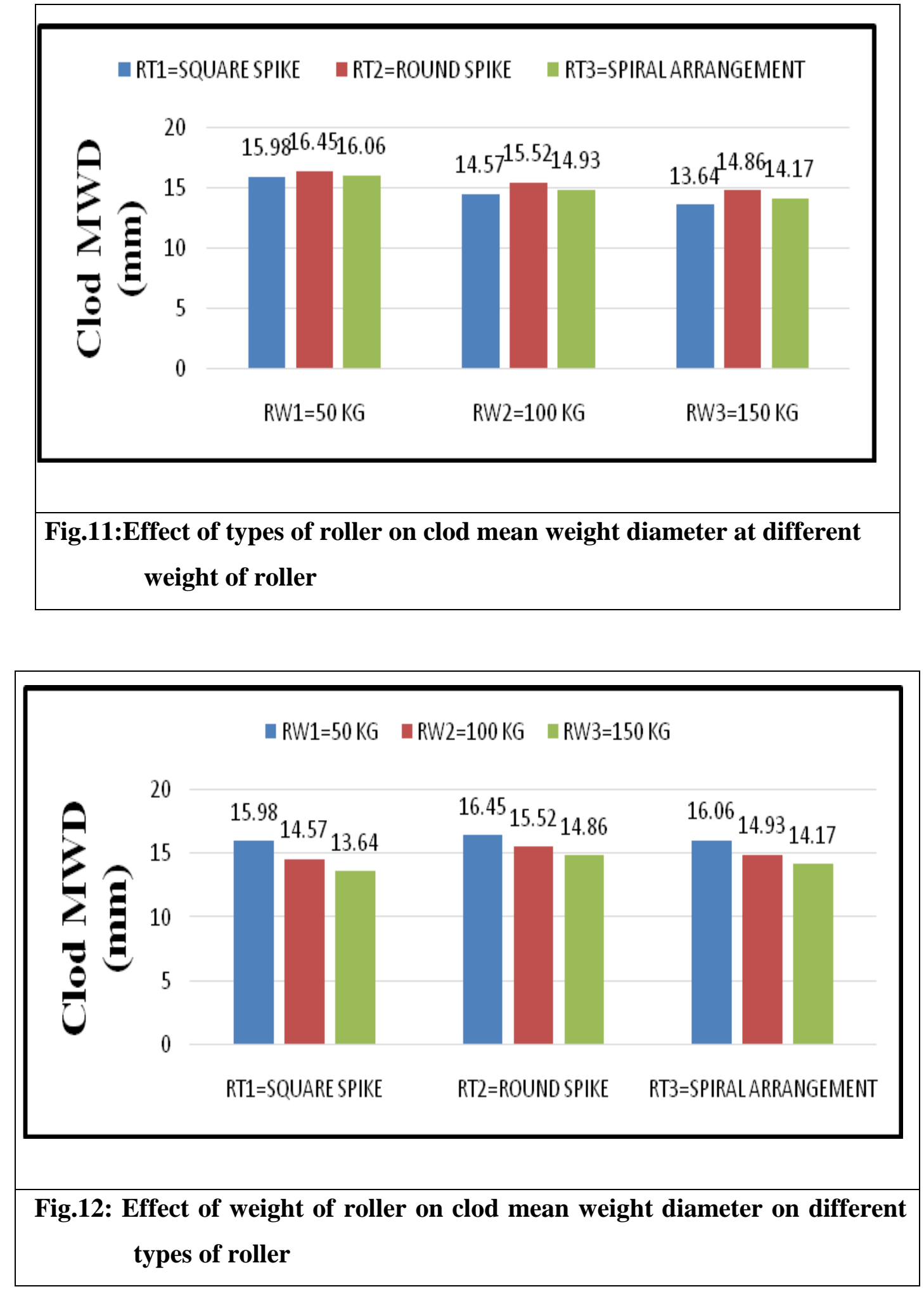

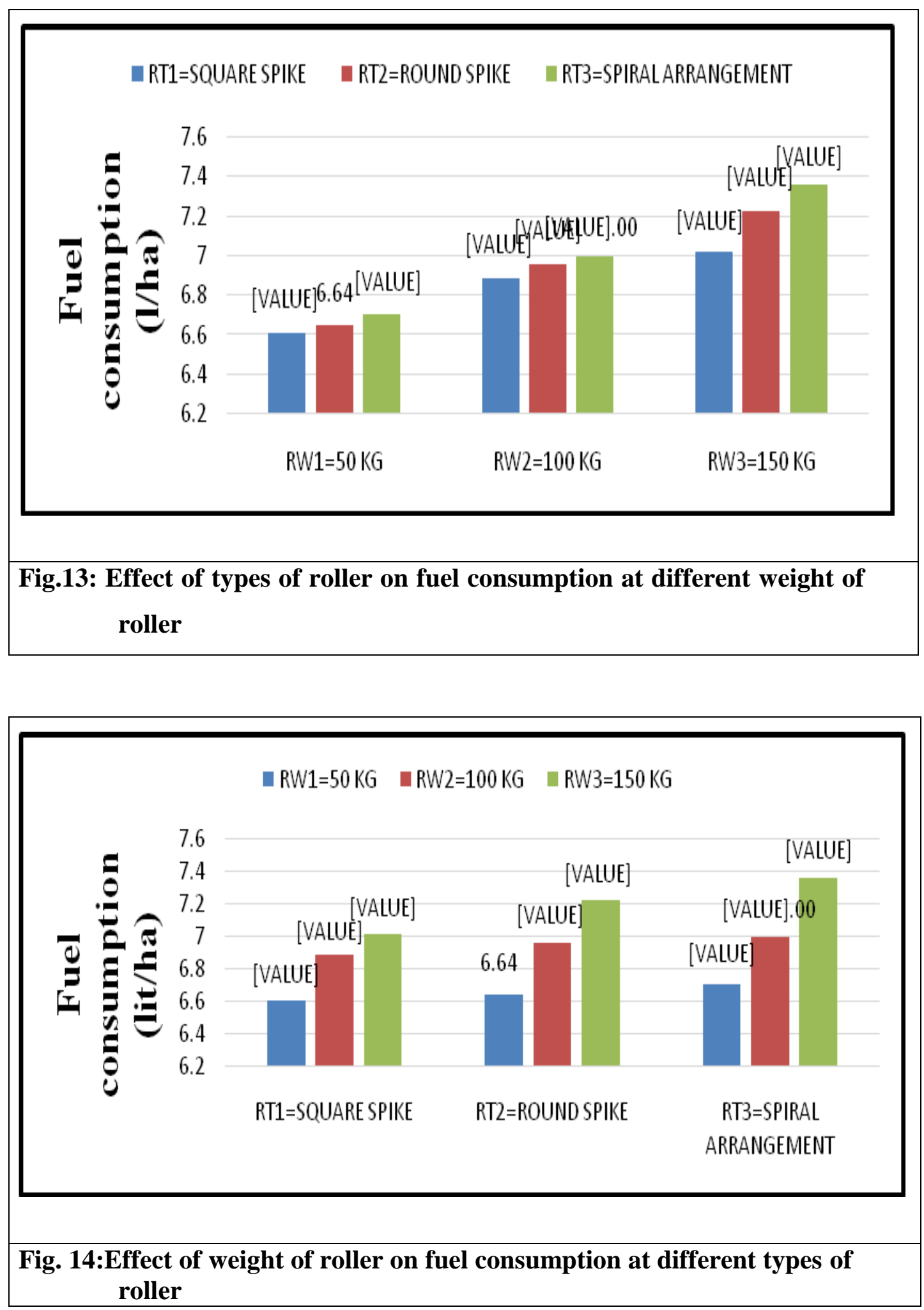

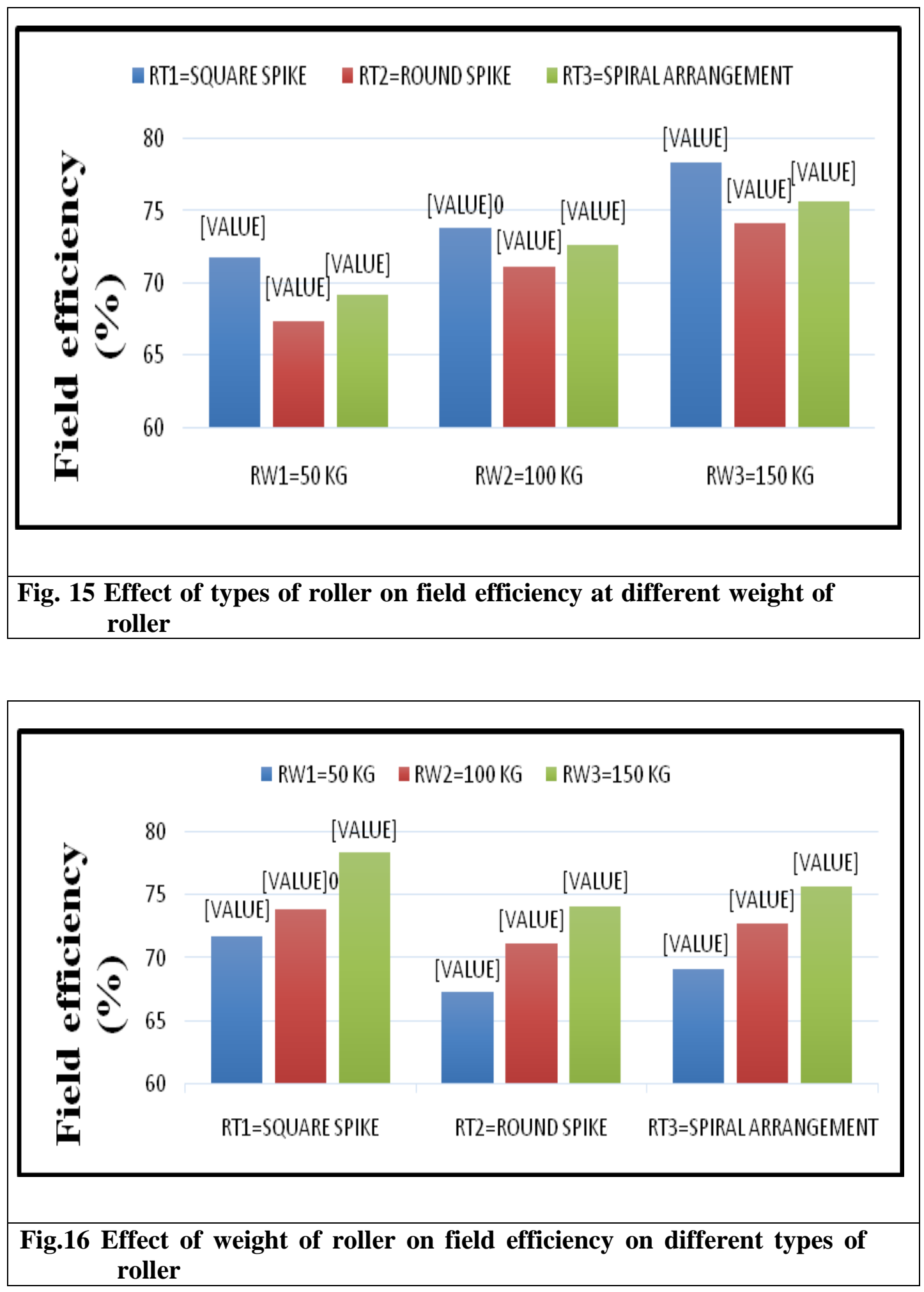
Effect of weight of roller on fuel consumption

The mean value of fuel consumption of three types of roller were compared and graphically presented in Figure 14. Minimum fuel consumption (6.611/ha) was observed corresponding to the weight of $50 \mathrm{~kg}$ and maximum fuel consumption (7.361/ha) was observed corresponding to the weight of 150 $\mathrm{kg}$.

Combined effect of types of roller and weight of roller on fuel consumption

The mean values of the fuel consumption and their significance are shown in Table 6.The interaction between types of roller and weight of roller was found significant at 5 per cent level of significance. The higher value of fuel consumption (7.36 1/ha) was obtained in case of spiral arrangement with spike type roller and $150 \mathrm{~kg}$ of weight.

\section{Field efficiency}

Field efficiency of the clod crusher during operation was observed and calculated. ANOVA for field efficiency on types/weight of roller are presented in Table 7. ANOVA shows that the types of roller and weight of roller both had significant effect on field efficiency at 5 per cent level. The interaction between types of roller and weight of roller also shows significant effect.

\section{Effect of types of roller on field efficiency}

The mean values of field efficiency at three types of roller were compared and presented in Table 8 and graphically presented in Figure 15. It shows that field efficiency of 74.64, 70.86 and $72.48 \%$ was observed corresponding to the roller of square spike, round spike and spiral arrangement. This table also indicates that the mean field efficiency was higher in case of square spike type roller.

\section{Effect of weight of roller on field efficiency}

The mean values of field efficiency on three weights of roller were compared and graphically presented in Figure 16. It shows that clod crushing field efficiency of 59.41, 72.53 and $76.04 \%$ was observed corresponding to the weight of roller of 50, 100 and $150 \mathrm{~kg}$. This table also indicates that the mean field efficiency was higher in case of more weight of roller.

\section{Combined effect of types of roller and} weight of roller on field efficiency

The mean values of the field efficiency and their significance are shown in Table 8. The interaction between types of roller and weight of roller was found significant at 5 per cent level of significance. The higher value of field efficiency $(78.37 \%$ ) was obtained in case of square spike and $150 \mathrm{~kg}$ of weight.

It is concluded as follows:

1. Clod crusher (square spike and $150 \mathrm{~kg}$ of weight) attachment to cultivator has shown better results with respect to quality of work. It breaks the clods properly and results in optimum value of clod MWD (13.64 mm) and bulk density $\left(1.18 \mathrm{~g} / \mathrm{cm}^{3}\right)$ which are preferable for seed bed preparation for this region.

2. The minimum slip (4.62\%) was obtained in case of clod crusher (square spike and $150 \mathrm{~kg}$ of weight) attachment to cultivator which consumed less fuel consumption as compared to other rollers with $150 \mathrm{~kg}$ of weight.

3. Higher effective field capacity was obtained $0.33,0.29,0.30 \mathrm{ha} / \mathrm{h}$ for clod crusher (square spike and $150 \mathrm{~kg}$ of weight), clod crusher (round spike and $150 \mathrm{~kg}$ of weight) and clod crusher (spiral 
arrangement of square spike and $150 \mathrm{~kg}$ of weight) respectively.

4. The field efficiency was obtained 78.37, 74.13 and $75.61 \%$ for clod crusher (square spike and $150 \mathrm{~kg}$ of weight), clod crusher (round spike and $150 \mathrm{~kg}$ of weight) and clod crusher (spiral arrangement of square spike and $150 \mathrm{~kg}$ of weight) respectively.

5. The fuel consumption was obtained 7.02, 7.23 and $7.36 \mathrm{l} / \mathrm{ha}$ for clod crusher (square spike and $150 \mathrm{~kg}$ of weight), clod crusher (round spike and $150 \mathrm{~kg}$ of weight) and clod crusher (spiral arrangement of square spike and $150 \mathrm{~kg}$ of weight) respectively.

6. The cost of operation using clod crusher cum plankerwas 882, 1050, $988 \square$ /hain square spike, round spike and spiral arrangement of square spike respectively.

7. It has been suggested to use the clod crusher cum planker (square spike with $150 \mathrm{~kg}$ of weight) for tillage/seedbed preparation.

\section{References}

Agrawal, S. K. and Singh, B. 1988. Investigation on evaluation of spiked clod crusher. Unpublished B. Tech (Agril. Engg.) Dissertation Submitted to G.B. Pant University of Agriculture and Technology, Pantnagar.

Anonymous. 2008. ICAR Annual Report. Available at http://www.icar.org.in/ ?q=en $/$ node/417 accessed $11^{\text {th }}$ September, 2016.

Anonymous. 2017. Development and performance of tractor drawn cultivator cum spiked roller. AGRESCO Report. Department of Farm Engineering. JAU, Junagadh.

Boydas, M. G. and Turgut, N. 2007. Effect of tillage implements and operating speeds on soil physical properties and wheat emergence. Turkish Journal of Agriculture and Forestry. 31(6): 399412.

Carman, K. 1997. Effect of different tillage systems on soil properties and wheat yield in middle Anatolia. Soil and Tillage Research. 40(3-4): 201-207.

Eghball, B., Mielke, L. N., Calvo, G. A. and Wilhelm, W. W. 1993. Fractal description of soil fragmentation for various tillage methods and crop sequences. Soil Science Society of America Journal. 57(5): 1337-1341.

Hunt, D. 2001. Farm Power and Machinery Management. A Blackwell Publishing Company, Iowa State Press, U.S.A.

IS: 2720-2: 1973. Methods of test for soils. Part II Determination of water content., BIS New Delhi.

IS: 7640: 1975. Test code for disc harrows., BIS New Delhi.

Johnson, C. B., Mannering, J. V. and Moldenhauer, W. C. 1979. Influence of surface roughness arid clod size and stability on soil and water losses. Soil Science Society of American Journal. 43(4): 772-777.

Kepner, R. A., Bainer, R. and Barger, E. L. 2005. Principles of Farm Machinery. CBS Publishing Company, New Delhi. pp. 24-29.

Maheshwari, T. K., Thakur, T. C. and Varshney, B. P. 2005. Spiked clod crusher and planker performance under different soil conditions. Agric. Engineering Today.29(3-4): 6-11.

Mehta, M. L., Verma, S. M., Mishra, S. K. and Sharma, V. K. 1995. Testing and Evaluation of Agricultural Machinery. National Agricultural Technology Information Centre, Ludhiana. pp. 57 68.

Pacharne, M. M., Savle, S. R., Sanglikar, R. V. and Pacharne, D. T. 2009. 
Development of ' $\mathrm{V}$ ' blade harrow. International Journal of Agricultural Engineering. 2(2): 266-269.

Panse, V. G. and Sukhatme, P. V. 1967. Statistical Methods for Agricultural Workers. Indian Council of Agricultural Research, New Delhi.

Patil, S. L. and Sheelavantar, M. N. 2009. Effects of tillage depths, organic amendments and nitrogen on yield of winter sorghum on a vertisol in south India. Journal of Sustainable Agriculture. 33(1): 28-50.

Punmia, B. C. and Jain A. K. 2005. Soil Mechanics and Foundations. Sixteenth Edition, Laxmi Publication, New Delhi. pp. 1-87.

Sahay, J. 2008. Element of Agricultural Engineering. Standard Publishers Distributors. Delhi. pp. 247-254.

Sahu, R. K. and Rahman, H. 2006. An approach for draft prediction of combination tillage implements in sandy clay loam soil. Soil and Tillage
Research. 90(1-2):145-155.

Sharma, D. N. and Mukesh, S. 2010. Farm Machinery Design: Principal and Problems. Jain Brothers. New Delhi. pp. 196-199.

Sharma, P. K. 2001. Clod Formation: A serious problem for wheat cultivation in rice wheat cropping sequence. Journal of Agricultural Physics. 1(1): 76-79.

Singh, C. P. and Panesar, B. S. 1991. Optimum combination of tillage tools for seedbed preparation of wheat after paddy harvest. Agricultural Mechanization in Asia, Africa and Latin America. 22(2): 18-22.

Yassen, H. A., Hassan, H. M. and Hammadi, I. A. 1992. Effects of plowing depth using different plow types on some physical properties of soil. Agricultural Mechanization in Asia, Africa and Latin America. 23(4): 2124.

\section{How to cite this article:}

Ginoya, C.J., R. Yadav, S.R. Zilpilwar, V.R. Vagadia and Agrawat, V. 2019. Development and Optimization of Mini Tractor Mounted Clod Crusher cum Planker. Int.J.Curr.Microbiol.App.Sci. 8(01): 1822-1838. doi: https://doi.org/10.20546/ijcmas.2019.801.193 